\title{
A REVIEW OF OPERATIONAL RESEARCH AND MATHEMATICAL METHODS FOR ENVIRONMENTAL MANAGEMENT APPLICATIONS IN INDUSTRY
}

\author{
A.C. Brent ${ }^{1}$ and C. Labuschagne ${ }^{2}$ \\ ${ }^{1}$ Chair in Life Cycle Engineering \\ Department of Engineering and Technology Management \\ University of Pretoria, South Africa \\ abrent@eng.up.ac.za \\ ${ }^{2}$ Department of Engineering and Technology Management \\ University of Pretoria, South Africa \\ carin.labuschagne@up.ac.za
}

\begin{abstract}
The principles of operational research (OR) and related mathematical methods have been applied to environmental issues for the past five decades. However, the increasing pressures experienced by industry over the last decade, pertaining to sustainable development performances, have renewed interests and intensified the potential application of OR techniques in environmental planning and management. The subsequent number of published mathematical models is vast. This paper aims to provide an overview of the modelling approaches to address the environmental impacts associated with industrial activities. In particular, the methods that are used to model the cross-boundary effects of industrial resource use and releases are summarised.
\end{abstract}

\section{OPSOMMING}

Die afgelope vyf dekades is verskeie wiskundige en operasionele navorsingmetodes (ON) aangewend om omgewingsprobleme te modelleer. Die toenemende druk wat die konsep van volhoubare ontwikkeling op die industrie plaas, het tot gevolg gehad dat die belangstelling in die moontlike toepassing van ON-tegnieke vir omgewingsbeplanning en bestuur drasties toegeneem het. Die doel van die artikel is om 'n oorsig te gee oor die modelleringstegnieke wat aangewend kan word om omgewingsimpakte aan te spreek. Daar word spesifiek gefokus op metodes om die omgewingsimpakte van hulpbrongebruik en vrystellings wat industriegrense oorsteek, te modelleer. 


\section{INTRODUCTION}

In 1987 the World Commission on Environment and Development (WCED) formally defined the concept of sustainable development as:

"development that meets the needs of the present without compromising the ability of future generations to meet their own needs" [1].

In response, government laws and policies are increasingly introducing the principles of sustainable development on a global scale, which in turn affect international trade agreements [1]. The concept of sustainable development is nevertheless inherently vague [2] and it remains difficult to express it in concrete, operational terms [3]. However, it is generally accepted that the three objectives of sustainable development are: social equity, economic efficiency, and environmental performance [4]. Businesses and industries, especially multinationals, are consequently pressurised to incorporate economic, environmental and social performances into policies, corporate cultures and decision-making processes [5, 6]. These performance objectives manifest in three operational focal points that are fundamental to the manufacturing industry:

- Projects, which drive change in internal operational practices. The concept of sustainable development must be integrated with the planning and management practices over the life cycles of projects [6].

- Assets, which are required in the manufacturing process. The life cycles of assets must be optimised in terms of sustainable development performances objectives of the manufacturing facility [7].

- Products, which determine the economic value of manufacturing operations. The influence of products (including materials and services) on economies, environments and society as a whole must be considered, i.e. the concept of product stewardship [8].

Generic tools have subsequently been developed to incorporate sustainable development into management practices in industry, e.g. to assess environmental performances throughout the life cycles of projects in the manufacturing sector [6], or to focus on the quantitative assessment of sustainability performances in product life cycles [9]. A majority of these tools have focused exclusively on the environmental dimension of sustainable development [6] and have gained worldwide acceptance through the ISO 14000 family of standards [10], which identifies the need to incorporate Environmental Management Systems (EMSs) into existing business practices [11].

\subsection{ISO 14000 standards for Environmental Management Systems (EMSs)}

The pressure experienced by companies to demonstrate improved environmental stewardship and the associated burden of the related accountability, resulted in the need for an international EMS standard. The consequence was the development and publication of the ISO 14000 family of standards within a period of two years by the International Organization for Standardization (ISO) [12]. ISO 14000 aims to achieve standardisation in the field of environmental management and clearly distinguishes between Environmental Management Systems (EMSs) and environmental management tools. The standards indicate that the implementation of an EMS is of central importance in establishing an environmental policy, 
objectives and targets for a company. The recommended environmental tools can assist a company in realizing these targets and objectives [12].

As is shown in Figure 1 [12], the ISO 14000 family of standards has distinguished two main focus areas for environmental tools that are applicable for industry:

- Organisation evaluation, including EMS, Environmental Performance Evaluation, and Environmental Auditing; and

- Product or process evaluation, including Life Cycle Assessment (LCA), Environmental Aspects in Product Standards, and Environmental Labelling.

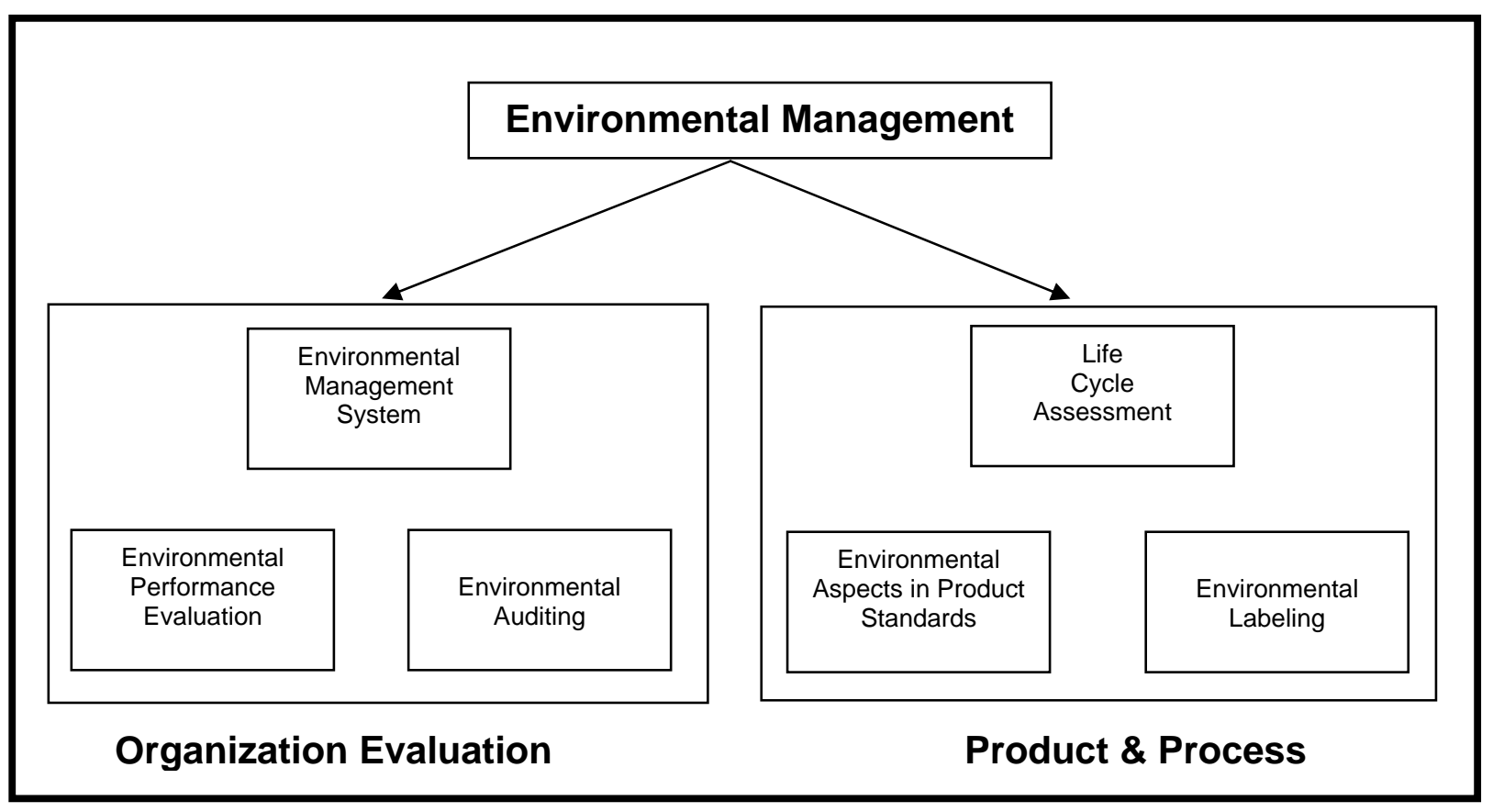

Figure 1: Focus areas of the ISO 14000 standard for EMS

\subsection{Mathematical modelling for industry Environmental Management Systems}

In industry, mathematical modelling is used for environmental performances, and product and process evaluations in EMSs. However, for all of these applications the purpose remains similar, i.e. to determine the detrimental anthropogenic impacts of industrial activities on the natural and human environment. These environmental impacts can be described by the environmental concerns that are influenced by the impacts, i.e. measurable changes in natural resources, as well as the temporal and spatial scales of the impacts, e.g. local, regional and global [13]. Typical environmental concerns with temporal and spatial scales are shown in Figure 2 [14].

A complication is that industrial activities influence more than one environmental concern. For example, typical manufacturing processes release emissions, solid waste and effluents, all of which have an impact on air, land and water resources. In order to address these impacts mathematical modelling in industry is used at three levels: 


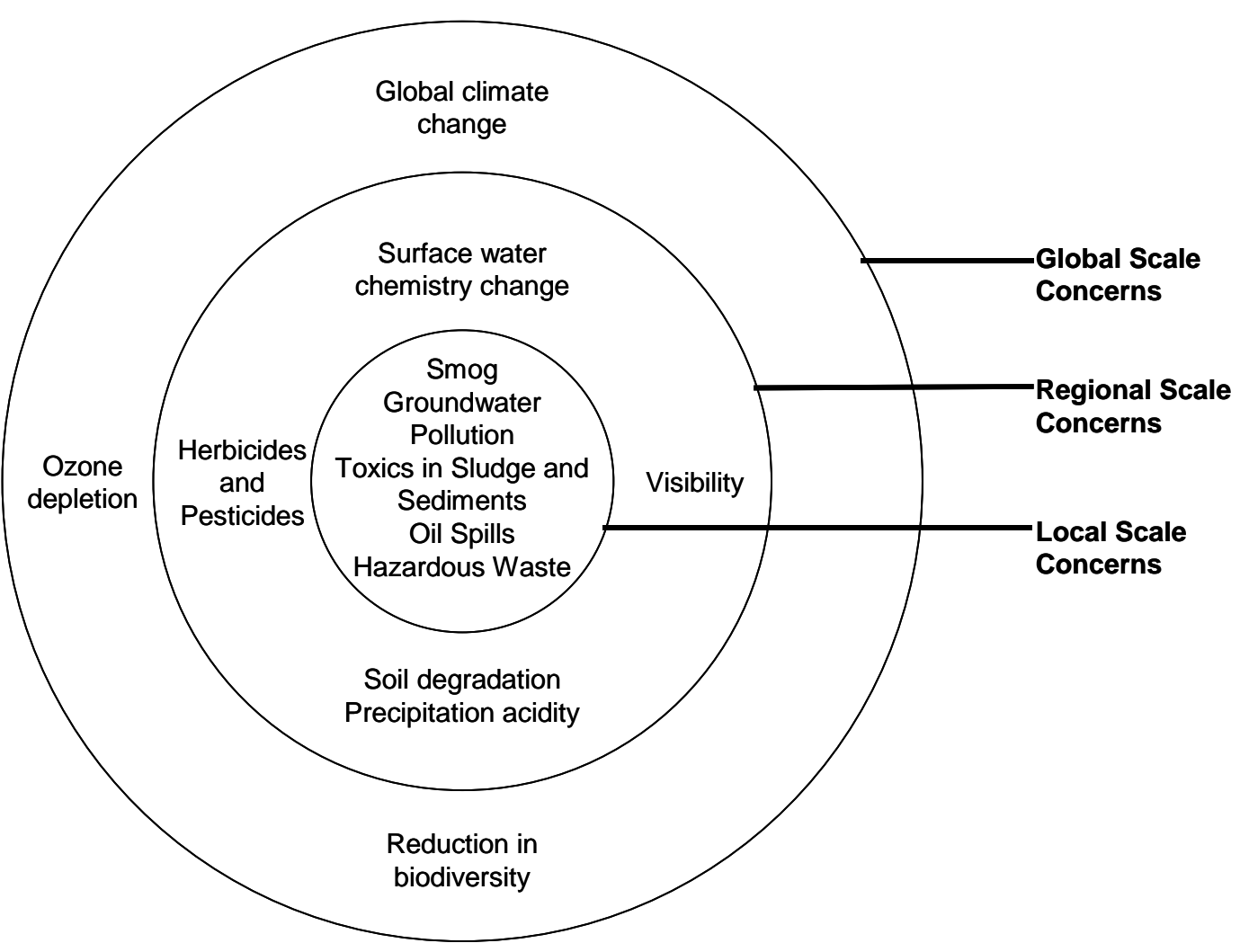

Figure 2: Typical environmental concerns at global, regional and local level

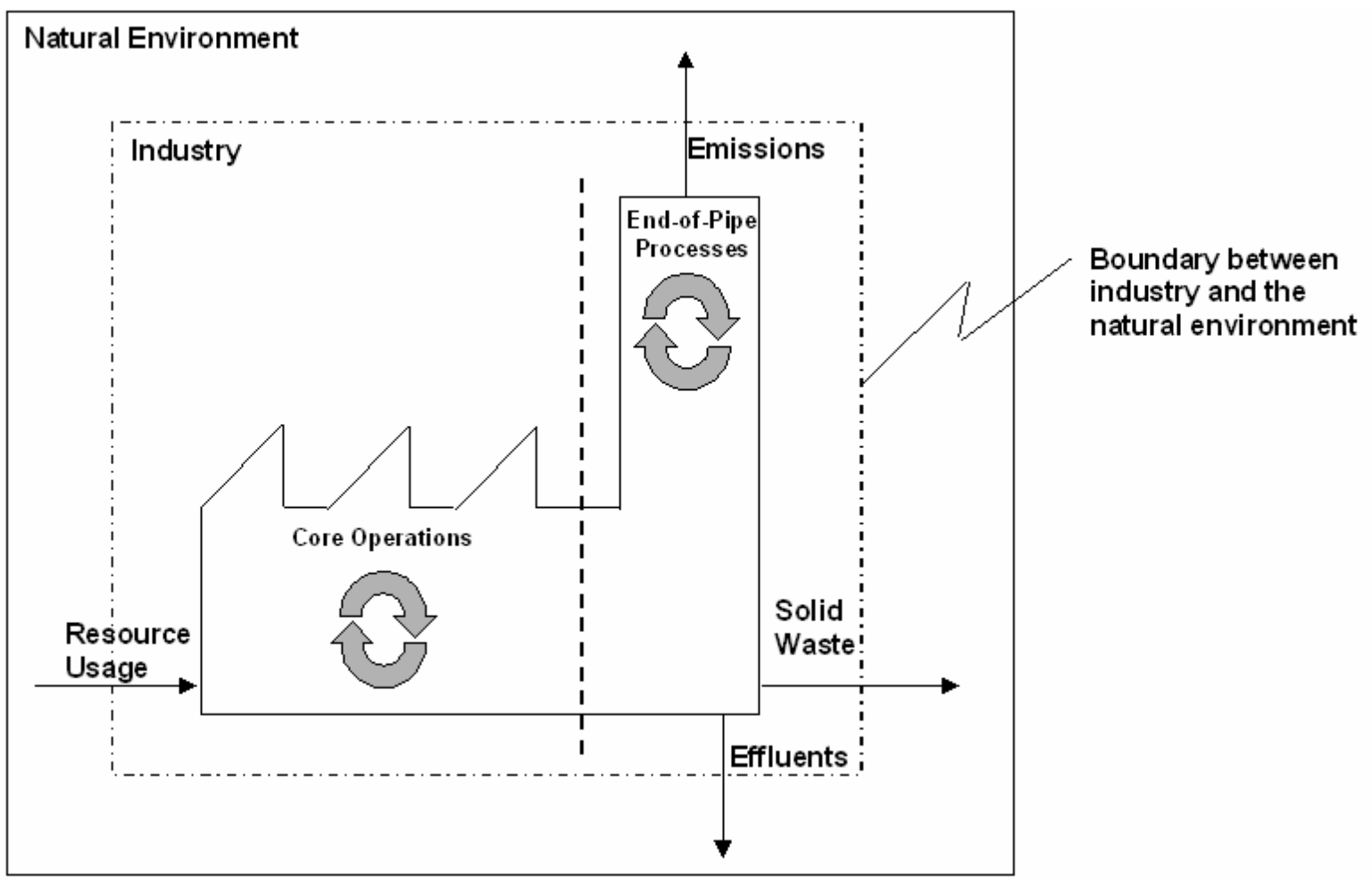

Figure 3: Focus of mathematical modelling to reduce environmental impacts 
- Optimisation of core operational processes. These processes incorporate on-site and offsite activities such as the supply chain, and typically include minimisation of waste (and pollutants) and resource use, e.g. energy and water.

- End-of-pipe process solutions, e.g. cleaning technologies for air emissions and treatment technologies for waste and effluents.

- Cross-boundary modelling of the impacts of industrial resource use and releases, such as emissions, waste and effluents, on local, regional and global natural resources.

The modelling of environmental impacts of operational process optimisation, end-of-pipe solutions and cross-boundary process parameters is summarised in Figure 3.

Process optimisation and end-of-pipe solution models are industry-specific. A wide variety of literature is available that describes these industry-specific applications of mathematical modelling, as well as other operational research (OR) techniques applied to environmental management $[15,16,17]$. The common characteristics of OR techniques in general to, and subsequent application for, environmental planning for sustainable development has been described in terms of [18]:

- Systems approaches: Holistic thinking is required in both fields.

- Interdisciplinary approaches: Expertise of other disciplines must be acquired in order to derive solutions to defined problems.

- Purposeful implementation approaches: Both fields can be described as problemdetermined and action-oriented activities.

It is subsequently impossible to provide an exhaustive review of all the applications (for industry) of mathematical modelling in environmental sciences [15]. Therefore, this article only summarizes the mathematical approaches that are used to model cross-boundary impacts of industry resource use and releases, including emissions, waste and effluents, on natural air, water, land and mined abiotic resources.

\section{THE EFFECT OF INDUSTRY ACTIVITIES ON HUMAN HEALTH AND ECOSYSTEM QUALITY}

An environmental impact has been defined as the cause-effect relationship between a source, the cause of the impact, and a receptor, the element affected by the impact [19]. The complexity of modelling the cross-boundary impacts therefore lies in the cause-effect chains, linking emissions and resource depletion to the consequences, as is shown in Figure 4 [20]. These cause-effect chains show that environmental impacts can be described at different impact levels. Table 1 uses the example of greenhouse gas releases to show different impact levels [21].

On the international front the Society of Toxicology and Chemistry (SETAC) and the United Nations Environmental Programme (UNEP) are formalising consistent conceptual models that are acceptable by the international scientific community and practical for industrial use. These models describe industrial impact effects at two distinct levels (see Figure 5) [22], namely midpoint and endpoint categories. 


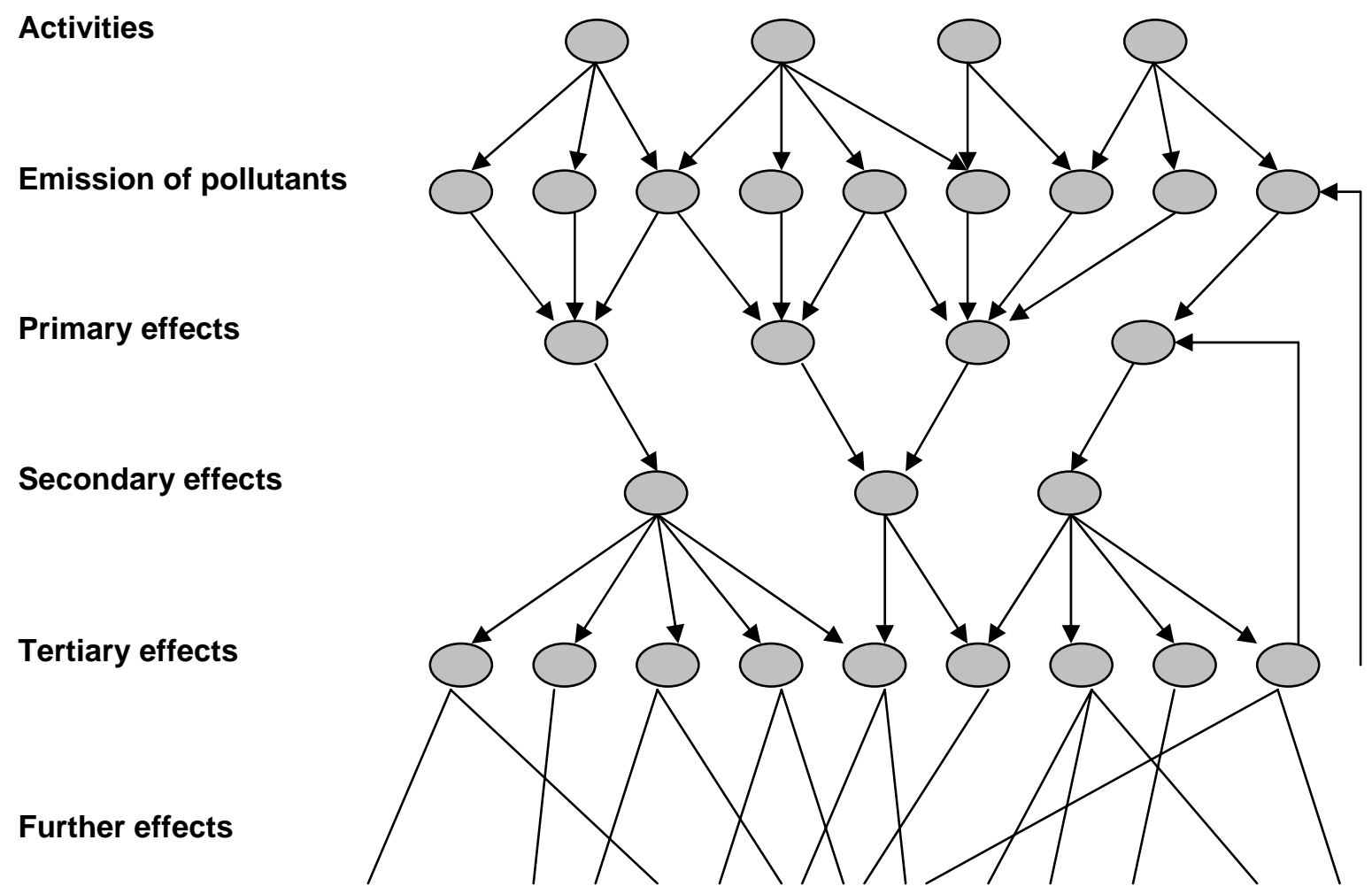

Figure 4: The cause-effect chain of industrial environmental impacts [20]

\begin{tabular}{|l|l|}
\hline Level & Cause - Effect \\
\hline Activity & Combustion processes, e.g. electricity generation from coal \\
\hline Pollutants emitted & Carbon dioxide $\left(\mathrm{CO}_{2}\right)$, methane $\left(\mathrm{CH}_{4}\right)$, etc. \\
\hline Primary effect & $\begin{array}{l}\text { Radiative forcing, i.e. absorption of thermal infra-red radiation in the } \\
\text { atmosphere }\end{array}$ \\
\hline Secondary effect & Increase in global temperature \\
\hline Tertiary effect & Ice-melting, rising sea levels, change in weather patterns \\
\hline Further effects & Specific changes in ecosystems \\
\hline
\end{tabular}

Table 1: Different levels of greenhouse gas release impacts [21]

\subsection{Midpoint Categories}

The first level at which industrial impacts can be described is the measurable effects on, or changes of, the natural resources, i.e. air, water, land, and non-renewable minerals and energy (mined abiotic) resources, due to industrial activities. At this level (for industrial releases) scientific fate and exposure analyses methods are used to describe:

- The fate of substances once released into the natural environment, e.g. ambient chemical or physical transformation and the dispersion and deposition of substances; and

- The final exposure of humans and ecosystems to the transformed and dispersed releases, e.g. the potential human body intake of transformed substances through inhalation, ingestion, etc. 


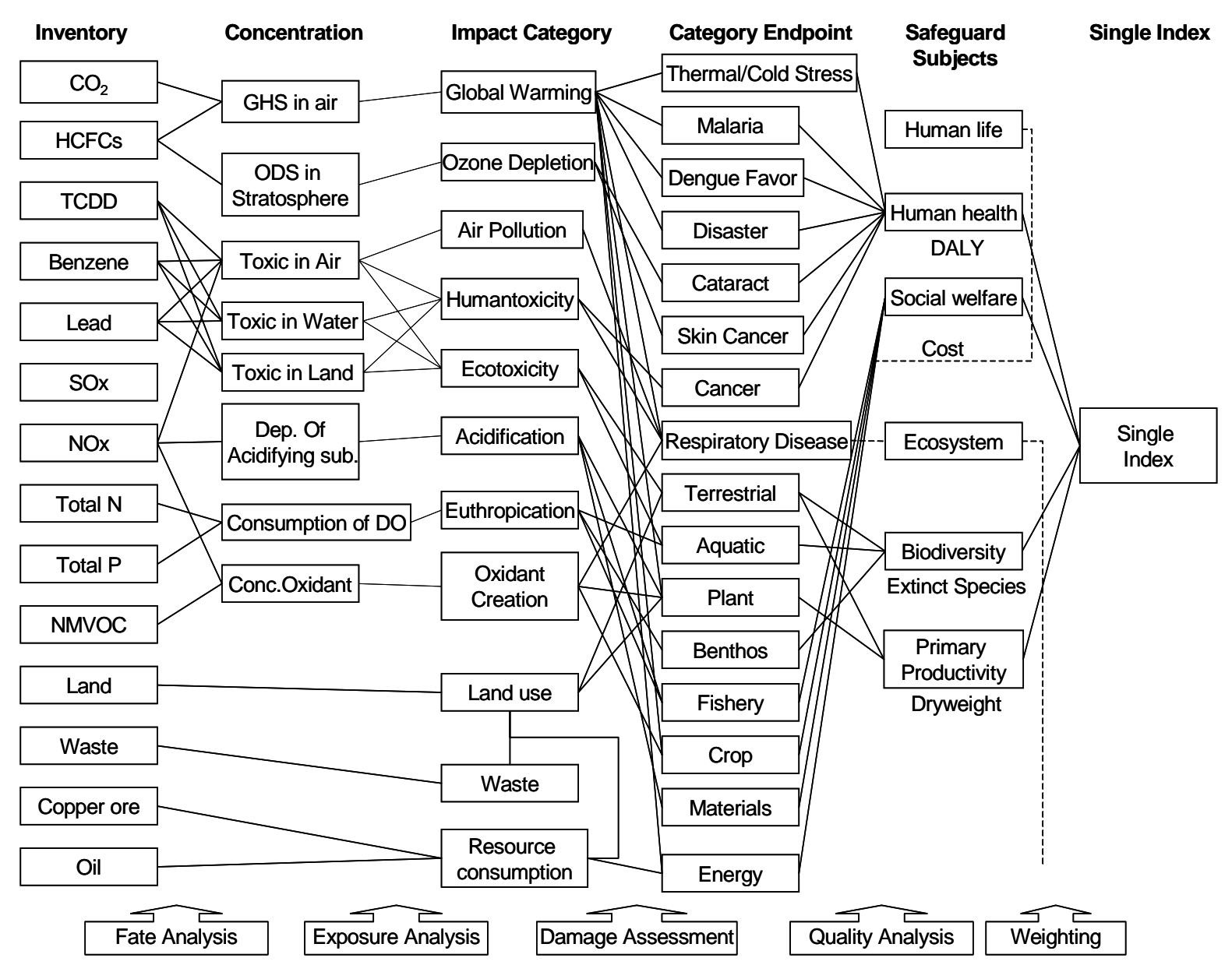

Figure 5: Levels of modelled environmental effects from industrial activities [22]

For resource use, the depletion rate of available reserves is typically considered. Furthermore, specific industrial resource use and environmental releases are translated to baseline changes caused by certain known depletions or releases. Thereby, the total cross-boundary inventory of an industrial activity is classified and characterised into certain impact categories that reflect changes in the natural resources. These categories are referred to as midpoint categories. The most common of these are shown under the heading 'impact category' of Figure 5.

\subsection{Endpoint Categories}

Potential effects on, or changes in, human health and ecosystem quality due to the changes in the natural resources represent the second level to describe industrial impacts. At this level it is attempted to translate the effects on the midpoint categories into possible effects on Safeguard Subjects (in Figure 5), i.e. human health and ecosystem quality. The categories that are used at this level are referred to as endpoint categories. For this procedure a damage assessment is required, e.g. an increased potential risk of cancer due to the exposure to a substance, as well as a quality analysis, e.g. the extent to which an increased potential risk of cancer would affect the quality of human health in a region. In South Africa, the four natural resource groups, i.e. water, air, land, and mined abiotic resource, have been defined as Areas of Protection (AoP) that must be sustained with respect to the Safeguard Subjects [23, 24]. 


\subsection{Industry Reaction}

These different levels of effects are considered (in-house) by industries due to regulatory and legislation requirements that enforce specific monitoring and assessments of industrial activities at the different spatial scales, e.g. air quality monitoring in a defined region, or Health Risk Assessments (HRAs) or Environmental Impact Assessments (EIAs) in a community. One approach is to convert the levels of effects into possible cost implications for internal decision-making purposes [25]. In some cases, weighting procedures are also used to obtain an overall perspective of the environmental performance of an industry activity. This is referred to as the 'single index' in Figure 5.

\section{MODEL APPLICATIONS AND OPERATIONAL RESEARCH AND MATHEMATICAL TECHNIQUES}

The first examples of the application of operational research optimisation models to environmental problems were published in the mid-seventies [15]. However, optimisation techniques were already applied in air quality management in the late 1960's while differential equation based descriptive plume models were used much earlier [16]. Furthermore, the application of operational research techniques to water resource and water quality management began in the late 1950's [26]. Nevertheless, academia has increasingly re-recognised the potential for operational research to make contributions to environmental management by the turn of the millennium [18, 27]; this may be attributable to the increased attention environmental management has received.

Operational research has been defined as the study of how to form mathematical models (collection of variables and relationships needed to describe pertinent features of a problem) of complex problems and how to analyze these problems (see Figure 6) [28]. The first step in any operational research model is therefore to identify the problem that is to be investigated. With respect to the cross-boundary environmental impacts of industry, the problem is to determine the impacts associated with the emissions, effluents and other waste streams, and resource-use, of operational activities along the cause-effect chain (see Figures 4 and 5).

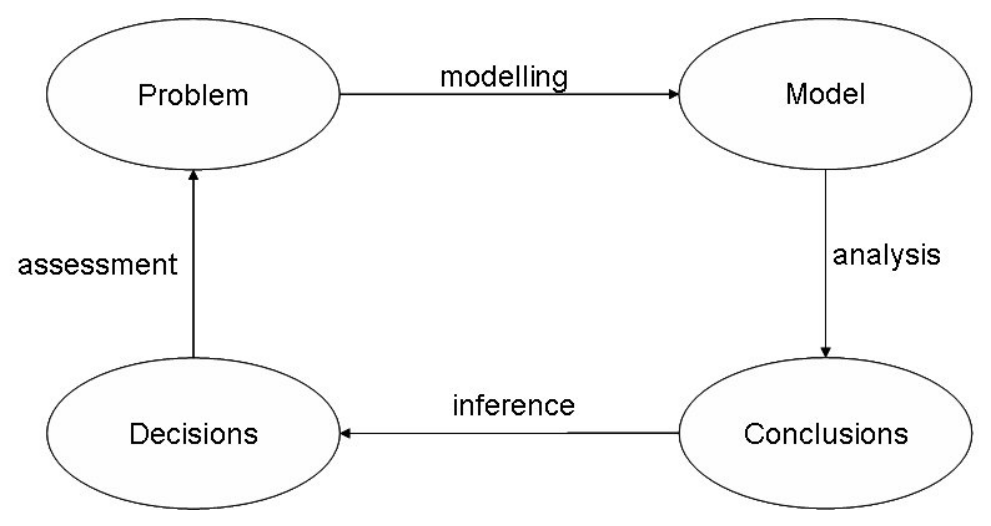

Figure 6: Operations Research Process [28]

The complexity of modelling these potential levels of impacts lies in the construction of purposeful, credible integrated models from data and prior knowledge or information that can explain the effects or outcomes satisfactory by linking causes and effects through the chain 
(Figure 5). If cross-boundary releases are only considered, the mathematical modelling of the individual pollutants emitted and the spreading thereof are thus crucial in the fate and exposure analyses stages. Thereafter, models are required to describe the possible changes in human health or ecosystem quality due to the outcomes of the fate and exposure analyses stages. Table 2 lists some examples of the model applications as well as operational research and mathematical techniques that are used during fate and exposure analyses, damage assessments and quality analysis. The table is therefore not comprehensive in terms of all the cross-boundary environmental models that have been derived.

Analyses of the results of a specific model (after the quality assessment) can result in additional decision problems. For example, a company may realise that although the air pollution conforms to emissions standards, there may be an additional risk of adverse impacts on human health in a community due to topographical locations. The question may then be posed of whether to increase pollution controls (i.e. production costs) to decrease the risk of the impacts. These decisions are addressed through process optimisation and end-of-pipe solution models (section 1.2) and can typically result in tradeoffs between costs and a pollution prevention strategy. For example, the new trends towards a more proactive approach favours pollution prevention above end-of-pipe solutions, and operational research techniques have been applied to study the short-term financial performance impacts due to this choice [43].

\begin{tabular}{|c|c|c|c|}
\hline $\begin{array}{l}\text { Effect } \\
\text { Level }\end{array}$ & $\begin{array}{l}\text { Analysis } \\
\text { Steps/ } \\
\text { Elements }\end{array}$ & Examples of model applications & Techniques \\
\hline \multirow{2}{*}{ Midpoint } & Fate & \multirow{2}{*}{ 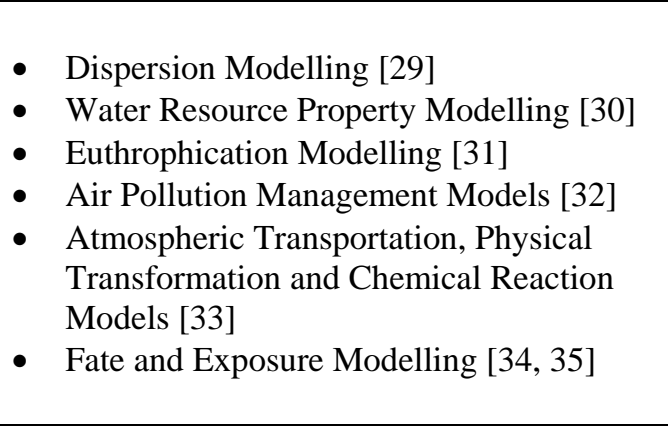 } & \multirow{2}{*}{$\begin{array}{ll}\text { - } & \text { Linear Programming; } \\
\text { - } & \text { Goal Programming; } \\
\text { - Stochastic Programming; } \\
\text { - } & \text { Non-linear programming } \\
\text { - } & \text { Simulation } \\
\text { - } & \text { Statistical Distributions e.g } \\
& \text { Gaussian } \\
\text { - } & \text { Differential Equations } \\
\text { - } & \text { Neural Networks } \\
\end{array}$} \\
\hline & Exposure & & \\
\hline \multirow[t]{2}{*}{ Endpoint } & $\begin{array}{c}\text { Damage } \\
\text { Assessment }\end{array}$ & \multirow{2}{*}{$\begin{array}{ll}\text { - } & \text { Dose-Response Models [36] } \\
\text { - } & \text { Damage Functions [37, 38, 39] } \\
\text { - } & \text { Human Health Impact Modelling [40] } \\
\text { - } & \text { Methodem of response function [42] }\end{array}$} & \multirow{2}{*}{$\begin{array}{l}\text { - Probability Modelling } \\
\text { - Bayesian Models }\end{array}$} \\
\hline & $\begin{array}{l}\text { Quality } \\
\text { Analyses }\end{array}$ & & \\
\hline
\end{tabular}

Table 2: Examples of model applications with operational research and mathematical techniques

\subsection{Applying existing operational research models to environmental problems}

Although environmental impacts are often modelled from basic principles using operational research methodologies, existing operational research techniques or models have been adapted to be used to address environmental problems, for example:

- A plant location model has been adapted as a location model for regional environmental 
facilities [44].

- A bicriteria knapsack problem has been used for planning remediation of contaminated sites [45].

- An m-Postman Chinese postman problem has been applied to determine solid waste collection routes [16].

\section{CONCLUSION - TOWARDS SUSTAINABLE DEVELOPMENT IN INDUSTRY}

Operational research models have been applied to environmental problems since the mid 1950 and 1960's. However, increased awareness has intensified the attention on environmental protection in industry. The consequence has been the re-discovery of the value of operational research models within environmental management [18]. Furthermore, the focus of industry is progressing towards a comprehensive sustainability approach that does not only address environmental aspects, but incorporates social impacts into decision-making as well. The need to evaluate the overall sustainability performances of operational activities is therefore increasing. This need offers interesting research opportunities within the field of operational research. As an example, the field of multi-criteria decision analysis has been proposed as an approach to consider the multiple aspects of sustainable development [46]. Also, the models proposed for the environmental evaluation of business practices based on the analytical network process [47] may (possibly) be extended to include social and economic performances as well.

The challenge to achieve sustainable development is a complex societal problem. Since the original aim of the operational research community was to handle complex societal problems as a whole [48], the application of operational research models and techniques to the sustainability challenge is unlimited.

\section{REFERENCES}

[1] Sampson, I. 2001. Introduction to a legal framework to pollution management in South Africa, Deloitte \& Touche and South African Water Research Commission report, no. TT 149/01, Pretoria.

[2] Daly, HE. 1990. 'Toward some operational principles of Sustainable Development', Ecological Economics, 2, pp. 1-6.

[3] Briassoulis, H. 2001. 'Sustainable Development and its Indicators: Through a (Planner's) Glass Darkly', Journal of Environmental Planning and Management, 44(3), pp. 409-427.

[4] Labuschagne, C., Brent, A.C., \& Van Erck, R.P.G. 2003. 'Assessing the Sustainability Performances of Industries', Journal of Cleaner Production, In Press.

[5] Brent, A.C., Rohwer, M.B., Friedrich, E., \& von Blottnitz, H. 2002. 'Overview: LCA in South Africa: Status of Life Cycle Assessment and Engineering Research in South Africa', International Journal of Life Cycle Assessment, 7(3), pp. 167-172.

[6] Labuschagne, C., Brent, A.C., \& Claasen, S.J. 2003. 'Environmental and social impact considerations for sustainable project Life Cycle Management in the process industry', Working paper ITB 2003/3, Department of Engineering and Technology Management, University of Pretoria.

[7] Schuman, C., \& Brent, A.C. 2003. 'Asset Life Cycle Management: Towards improving asset performance', Working paper ITB 2003/4, Department of 
Engineering and Technology Management, University of Pretoria.

[8] United States Environmental Protection Agency (EPA). 2003. Product Stewardship, http://www.epa.gov/epaoswer/non-hw/reduce/epr/ accessed on 8 June 2004.

[9] United Nations Environmental Programme (UNEP). 2004. 'The life cycle initiative - UNEP/SETAC co-operation on best available practice in Life Cycle Assessment (LCA)', http://www.uneptie.org/pc/sustain/lcinitiative/ accessed on 8 June 2004.

[10] Robèrt K-H, Schmidt-Bleek B, Aloisi de Larderel J, Basile G, Jansen JL, Kuehr R, Price Thomas P, Suzuki M, Hawken P, Wackernagel M. 2002. 'Strategic sustainable development - selection, design and synergies of applied tools', Journal of Cleaner Production, 10, pp. 197-214.

[11] New Steel Metal Bulleting. 2003. ISO 14000 and environmental-management systems, http://www.newsteel.com/2000/NS0007en.htm accessed on 8 June 2004.

[12] Tibor, T., \& Feldman, I. 1996. ISO 14000: a guide to the new environmental management standards, Irwin, Chicago.

[13] Graedel, T.E. 1998. Streamlined Life Cycle Assessment, Prentice Hall, New Jersey.

[14] Graedel, T.E., \& Allenby, B.R.1995. Industrial Ecology, Prentice Hall, New Jersey.

[15] Bloemhof-Ruwaard, J.M., Van Beek, P., Hordijk, L. \& Van Wassenhove, L.N. 1995. 'Interactions between operational research and environmental management', European Journal of Operational Research, 85, pp. 229-243.

[16] ReVelle, C. 2000. 'Research Challenges in environmental management', European Journal of Operational Research, 121, pp. $218-231$.

[17] Debets, F.J.C. \& Van Wassenhove, L.N. 1992. 'A guided tour through applications of OR-techniques to environmental problems', INSEAD Working Paper 92/24/TM, Fontainbleau, France.

[18] Midgley, G., \& Reynolds, M. 2004. 'Systems/operational research and sustainable development: A new agenda’, Sustainable Development, 12, pp. 56-64.

[19] Julien, B., Fenves, S.J., \& Small, M.J. 1992. 'An Environmental Impact Identification System', Journal of Environmental Management, 36, pp.167-184.

[20] Finnveden, G., Andersson-Sköld, Y., Samuelsson, M.O., Zetterberg, L., \& Lindfors, L.G. 1992. 'Classification (impact analysis) in connection with life cycle assessment - a preliminary study', In: Product Life Cycle Assessment - Principles and Methodology, Nordic Council of Ministers, Copenhagen.

[21] Baumann, H., \& Tillman, A.M. 1999. The hitchhiker's guide to LCA, Technical Environmental Planning, Chalmers University of Technology, Göteborg.

[22] United Nations Environmental Programme (UNEP). 2004. The life cycle initiative - Life Cycle Impact Assessment Programme, http://www.uneptie.org/pc/sustain/lcinitiative/lcia_program.htm accessed on 8 June 2004.

[23] Brent, A.C. 2004. 'A Life Cycle Impact Assessment procedure with resource groups as Areas of Protection', International Journal of Life Cycle Assessment, 9(3), pp. 172179.

[24] Brent, A.C., \& Visser, J.K. 2004. 'An Environmental Performance Resource Impact Indicator for Life Cycle Management in the manufacturing industry', Journal of Cleaner Production, in print.

[25] American Institute of Chemical Engineers (AIChE). 1999. Total Cost Assessment Methodology: Internal Managerial Decision Making Tool. An AIChE publication, Center for Waste Reduction Technologies (CWRT), 
http://www.aiche.org/cwrt/projects/cost.htm accessed on 8 June 2004.

[26] Maas,A., Hufschmidt, M., Dorfman, R., Thomas, H., Marglin, S., \& Fair, G. 1962. The design of Water Resource Systems, Harvard University Press, Cambridge.

[27] Corbett, C.J., \& Pan, J-N. 2002. 'Evaluating environmental performance using statistical process control techniques’, European Journal of Operations Research, 139, pp. 68-83.

[28] Rardin, R.L. 1998. Optimization in Operations Research, Prentice Hall, New Jersey.

[29] United States Environmental Protection Agency (EPA). 2004. Guideline on Air Quality Models, Appendix W to Part 51, Chapter 1, Code of Federal Regulations (CFR) Title 40: Protection of the Environment, http://www.epa.gov/epahome/cfr40.htm accessed on 8 June 2004.

[30] Maier, H.R., \& Dandy, G.C. 2001. 'Neural networks for the prediction and forecasting of water resources variables: a review of modelling issues and applications', Environmental Modelling and Software, 15, pp.101-124.

[31] Somlyòdy, L. \& Wets, R.J-B. 1988. 'Stochastic Optimization models for Lake Eutrophication Management', Operations Research, 36(5), pp. 660-681.

[32] Cooper, W.W., Hemphill, H., Huang, Z., Li, S., Lelas, V., \& Sullivan, D.W. 1996. 'Survey of Mathematical programming models in air pollution management', European Journal of Operations Research, 96(1), pp. 1-35

[33] United States Environmental Protection Agency (EPA). 2002. Models-3 Advanced Air Quality Modeling, Atmospheric Modeling Models, Atmospheric Modeling Division, http://www.epa.gov/AMD/models3_intro.html accessed on 8 June 2004.

[34] Beck, A., Scheringer, M. \& Hungerbühler, K. 2000. 'Fate Modelling within LCA', International Journal of Life Cycle Assessment, 5(6), pp.335-344.

[35] Huijbregts, M.A. 1999. Priority Assessment of Toxic Substances in the frame of LCA. Development and Application of the Multi-media Fate, Exposure and Effect model USES-LCA, Faculty of Environmental Sciences, University of Amsterdam, the Netherlands.

[36] United States Environmental Protection Agency (EPA). 2002. A review of the reference dose and reference concentration processes, Risk Assessment Forum, Final report, EPA630/P-02/002F, Integrated Risk Information System (IRIS), http://www.epa.gov/IRIS/ accessed on 8 June 2004.

[37] Rabl, A. 1996. 'Air pollution damages and costs: An analysis of uncertainties', Proceedings of the Society of Risk Analysis Europe, University of Surrey, pp. 185188.

[38] Liu, B-C., \& Yu, E.S-H. 1976. Physical and economic damage functions for air pollutants by receptor, Midwest Research Institute (MRI) project no. 4004-D, United States Environmental Protection Agency (EPA) contract no. 68-01-2968, EPA-600/576-011, Washington DC.

[39] European Commission DG Research. 2001. ExternE - Externalities of Energy, http://externe.jrc.es/overview.html accessed on 8 June 2004.

[40] Murray, C., Lopez, A. 1996. The Global Burden of Disease, WHO, World Bank and Harvard School of Public Health. Boston.

[41] Goedkoop, M., Hofstetter, P., Müller-Wenk, R., Spriemsma, R. 1998. 'The EcoIndicator 98 Explained', International Journal of Life Cycle Assessment, 3(6), pp.352360.

[42] Malkina-Pykh, I.G. 2002. 'Integrated assessment models and response function models: Pros and cons for sustainable development indices design', Ecological 
Indicators, 2(1-2), pp. 93-108.

[43] Sarkis, J., \& Cordeiro, J.J. 2001. 'An empirical evaluation of environmental efficiencies and firm performance: Pollution prevention versus end-of-pipe practices', European Journal of Operational Research, 135(1), pp.102-113.

[44] Zhu, Z.P., ReVelle, C., \& Rosing, K. 1989. 'Adaptation of the plant location model for regional environmental facilities and cost allocation strategy', Annals of Operations Research, 18, pp. 345-366.

[45] Jenkins, L. 2002. 'A bicriteria knapsack program for planning remediation of contaminated lightstation sites', European Journal of Operational Research, 140 (2), pp. 427-233.

[46] Petrie J, Basson L, Stewart M, Notten P, Alexander B. 2001. 'Decision Making for Design of Cleaner Processes: A Life Cycle Management Perspective', Proceedings of the First International Conference on Life Cycle Management: Bridging the Gap between Science and Application.

[47] Sarkis, J. 1998. 'Evaluating environmentally conscious business practices', European Journal of Operational Research, 107(1), pp. 159-174.

[48] Bowen, K.C. 1983. A methodology for problem-formulation, Ph.D. Thesis, University of London, United Kingdom 
